\title{
Effect of Calcium Carbide Waste Powder on Some Engineering Properties of Bamboo Leaf Ash Concrete
}

\author{
Olumuyiwa Samson Aderinola, Olasunkanmi Eniola Omolola, Ajibola Ibrahim Quadri \\ Civil Engineering Department, The Federal University of Technology, Akure Nigeria \\ Email: osaderinola@futa.edu.ng,olasunkanmiomolola@gmail.com, aiquadri@futa.edu.ng
}

How to cite this paper: Aderinola, O.S., Omolola, O.E. and Quadri, A.I. (2018) Effect of Calcium Carbide Waste Powder on Some Engineering Properties of Bamboo Leaf Ash Concrete. Open Access Library Journal, 5: e4990.

https://doi.org/10.4236/oalib.1104990

Received: October 17, 2018

Accepted: November 20, 2018

Published: November 23, 2018

Copyright ( 2018 by authors and Open Access Library Inc.

This work is licensed under the Creative Commons Attribution International License (CC BY 4.0).

http://creativecommons.org/licenses/by/4.0/

\section{(c) (i) Open Access}

\begin{abstract}
The assessment of cement partially replaced with calcium carbide waste powder, CCWP and bamboo leaf ash, BLA on the strength of concrete made with cement was investigated. Oxide composition analysis of CCWP and BLA confirm their status as non-pozzolanic material rich in $\mathrm{CaO}$ component and pozzolanic materials, respectively. Setting times, slump, compressive and microstructure analysis tests were conducted on fresh and hardened concrete. Twenty-eight (28) and fifty-six (56) days peak compressive strength values of $13.23 \mathrm{~N} / \mathrm{mm}^{2}$ and $15.97 \mathrm{~N} / \mathrm{mm}^{2}$ respectively were obtained when $5 \%$ CCWP was mixed with 5\% BLA plus $90 \%$ cement. Values comparable to 28 and 56 days peak compressive strength values of $13.03 \mathrm{~N} / \mathrm{mm}^{2}$ and $15.07 \mathrm{~N} / \mathrm{mm}^{2}$ respectively obtained when cement was only used as a binder. The use of CCWP and BLA in concrete will ensure economy in concrete production and a better way of disposing these wastes.
\end{abstract}

\section{Subject Areas \\ Civil Engineering}

\section{Keywords}

Calcium Carbide Waste Powder (CCWP), Bamboo Leaf Ash (BLA), Cement, Concrete, Compressive Strength, Workability, Setting Time, Interfacial Bond

\section{Introduction}

The possibility of incorporating wastes from industrial or agricultural processes in the construction industry is borne out of the need to provide sustainable materials for construction. This is achieved either by searching for or incorporating 
new materials and products that are more environmental friendly and/or contributing towards the reduction of carbon dioxide emission into the atmosphere [1].

Research trends in materials development have also focused on providing alternatives necessitated by the high cost of conventional materials, and challenges in accessing fund for construction/building development, amongst many other reasons. The alternatives to conventional materials include use of pozzolanas as substitutes to cement or as mineral admixtures and use of other binders from agricultural wastes and by-products from industrial processes as admixtures or additives. In many developing countries the demand for building construction materials such as Ordinary Portland cement and admixtures is high to meet the infrastructure needs of the citizens [2].

Agricultural and industrial byproducts regarded as wastes in technologically underdeveloped societies could be used as partial replacement of Portland cement to achieve this purpose. Efforts have recently been focused on such substitute materials in making cement composites such as concrete and sand Crete [3]. Blended cements are currently used in many parts of the world [4]. When a pozzolan is blended with Portland cement it reacts with the lime to produce additional calcium-silicate-hydrate $(\mathrm{C}-\mathrm{S}-\mathrm{H})$, which is the main cementing compound. Thus, the pozzolanic material reduces the quantity of lime and increases the quantity of C-S-H. Therefore, the cementing quality is enhanced if a pozzolan is blended in suitable quantity with Portland cement [5].

According to [6], calcium carbide waste (CCW) is a byproduct obtained from the acetylene gas $\left(\mathrm{C}_{2} \mathrm{H}_{2}\right)$ production process as shown in Equation (1).

$$
\mathrm{CaC}_{2}+2 \mathrm{H}_{2} \mathrm{O} \rightarrow \mathrm{C}_{2} \mathrm{H}_{2}+\mathrm{Ca}(\mathrm{OH})_{2}
$$

Research findings have indicated that Calcium Carbide Waste, when combined with certain pozzolanas such as fly ash, silica fume, etc., containing high silicon dioxide and aluminum oxide could due to pozzolanic reactions yield final products that are like those obtained from cement hydration process. More researches are still being conducted on use of Calcium Carbide Waste in construction.

$$
\mathrm{CaO}+\mathrm{S}_{\mathrm{i}} \mathrm{O}_{2}+\mathrm{H}_{2} \mathrm{O} \rightarrow \mathrm{C}-\mathrm{S}-\mathrm{H}
$$

(Calcium Carbide Waste Powder) + (Bamboo Leaf Ash $) \longrightarrow$ Calcium Silicate Hydrate.

From Equation (2), it is observed that calcium carbide waste contains some cement chemical composition. Research findings have indicated that Calcium Carbide Waste, when combined with certain pozzolans such as fly ash, silica fume, etc., containing high silicon dioxide and aluminum oxide could due to pozzolanic reactions yield final products that are like those obtained from cement hydration process [7].

$\mathrm{X}$-Ray Fluorescence Spectrometer is an effective non-destructive technique of analyzing the elemental and oxide crystal composition of a material [8]. Compressive strength is a measure of the concrete's ability to resist load which tends 
to crush it. Compressive and tensile strength tests are two major strength tests conducted on concrete. Strength normally gives an overall picture of the quality of a concrete because it is directly related to the structure of the cement paste. Compression test of the concrete specimen is most widely used test to measure its compressive strength [9]. Therefore, these methods were simultaneously utilized in this research work to maximally bring out the features and microstructure behavior of these wastes.

This research is set out to investigate the use of the mix of an industrial waste, Calcium Carbide Waste Powder (CCWP) and an agricultural waste, Bamboo Leaf Ash (BLA) as partial replacement of cement in concrete, determine the compressive strength and workability of the concrete. This may be a cheaper alternative to conventional admixtures, which may lead to reduction in the cost of construction. This may also be a means of addressing the environmental pollution caused by the accumulation of the waste.

\section{Aim and Objectives}

The aim is geared towards using calcium carbide waste and bamboo leaf ash as partial replacement of cement in bid to achieve this aim, the specific objectives are to:

- determine the chemical composition of calcium carbide waste powder (CCWP), bamboo leaf ash (BLA) and Ordinary Portland cement (OPC).

- carry out compressive strength and other investigations on the concrete cubes that contain CCWP and BLA.

- determine the interlocking property of concrete containing both wastes.

\section{Materials and Methodology}

The materials used in this research work were Calcium carbide waste powder (CCWP), Bamboo leaf ash (BLA), sand (fine aggregate), granite (coarse aggregate), cement (OPC, Dangote type) and clean water for mixing as well as the curing medium. These materials were all gotten with Akure metropolis.

Sample Collection: Calcium carbide waste was collected from panel beaters' workshops within Akure metropolis, sun-dried, grinded and sieved through British sieve $0.075 \mathrm{~mm}$ to produce the calcium carbide waste powder (CCWP) and Bamboo leaves were collected as the fall off from the main bamboo trees behind the students' union building of federal university of technology Akure was collected. The bamboo dried bamboo leaves were dried and heated in the furnace to a temperature of $600^{\circ} \mathrm{C}$ for 1 hour to form BLA.

Methods of Physical Analysis. Particle size distribution analysis (with minimum sieves size $75 \mu \mathrm{m}$ ) as well as the hygrometer test were carried out for the fine aggregate obtained while aggregate crushing value (ACV) and aggregate impact value (AIV) tests were done for the granites. The particle size distribution curve for the fine aggregate was plotted.

Aggregate Crushing Value ( $A C V$ ) Test: To determine the ACV for the gra- 
nites, the aggregate passing through $12.5 \mathrm{~mm}$ and retained on $10 \mathrm{~mm}$. British Standard (BS) sieve were oven dried at a temperature of $100^{\circ} \mathrm{C}-110^{\circ} \mathrm{C}$ for $3-4$ hours. The cylinder was filled in three layers, each layer tamped with 25 strokes of the tamping rod. The weight of the aggregate was measured and recorded as $A$. The surface of the aggregate was then leveled, and the plunger inserted. The apparatus was then placed in the compression testing machine and loaded at a uniform rate until the sample fails. The sample was then sieved through a 2.36 $\mathrm{mm}$ BS sieve and the fraction passing through the sieve was weighed as $B$. The ACV was calculated using Equation (3).

$$
\operatorname{ACV}(\%)=(B / A) \times 100
$$

Aggregates impact Test: Also, the AIV test was done to determine the aggregate impact value of coarse aggregates according to [10] [11]. The sample was oven dried for 4 hours at a temperature of $100^{\circ} \mathrm{C}-110^{\circ} \mathrm{C}$ and cooled. The cylinder was loaded with the aggregates in three layers and tamped with 25 strokes of the tamping rod at each filling. The net weight of the aggregates was determined as A. The cup of the impact testing machine was fixed firmly in position on the base of the machine and the whole of the test sample placed in it and compacted with 25 strokes of the tamping rod. The hammer was raised to $380 \mathrm{~mm}$ above the upper surface of the aggregates in the cup and allowed to fall freely onto the aggregates. The test sample was subjected to a total of 15 such blows, each being delivered at an interval of not less than one second. The sample was removed and sieved through a $2.36 \mathrm{~mm}$ sieve. The fraction passing through was weighed as $Y$. The ratio of the weight of the fines formed, $Y$ to the total sample, $X$ was expressed as a percentage as shown in Equation (4). The test was repeated thrice, and the mean value was calculated.

$$
\operatorname{AIV}(\%)=(Y / X) \times 100
$$

Methods of Chemical Analysis: Chemical tests were carried out on the CCWP and BLA to determine their chemical properties. Chemical analyses were conducted with the aid of X-ray fluorescence (XRF) spectrometry (XRF machineModel X-supreme 8000 by Oxford instrument) and the various percentages of oxides present in the ash and powder were displayed on the screen as well as scanning electron microscope. Moisture content, soundness and loss of ignition tests were also carried out on these materials.

$X$-Ray Fluorescence Analysis. Mini Pal 4 Energy dispersive X-ray fluorescence (XRF) bench-top spectrometer was also used to perform nondestructive chemical analysis of elemental oxides present in the different wastes used. The CCWP and BLA were loaded into the sample holder and placed in the appropriate sample tray. The test was carried out by bombarding the samples with high energy $\mathrm{X}$-rays which resulted into emission of characteristics secondary X-rays. Using silicon drift detector, the elemental analysis and oxide composition were determined and printed out through the attached computer and printer.

Scanning Electron Microscopic Analysis: In carrying out SEM analysis, the paste samples (of about $25 \mathrm{~mm}$ diameter) were prepared to fit in into the speci- 
men chamber and they were mounted rigidly on the specimen stub. Their surfaces were polished to an ultra-smooth surface and were coated with carbon. Secondary electron detectors were used, and the data were displaced by a computer device.

Loss on Ignition Test. Loss on ignition test was done by heating up CCWP and BLA to a temperature between $900^{\circ} \mathrm{C}$ to $1000^{\circ} \mathrm{C}$ until a constant weight was obtained. The test was conducted to determine the organic matter present in a sample. The weight of the various samples due to heating was then determined and recorded using Equation (5).

where; $W_{1}=$ Weight of empty crucible $(\mathrm{g}), W_{2}=$ Initial weight $(\mathrm{g})$ of crucible and sample before heating and $W_{3}=$ Final weight $(\mathrm{g})$ of crucible and sample after heating for 25 minutes and cooling for 20 minutes.

$$
\text { Loss on Ignition }(\%)=\left(W_{2}-W_{3}\right) /\left(W_{2}-W_{1}\right) \times 100
$$

Test and Analysis of Concrete Specimens: Concrete specimens of size 150 $\mathrm{mm} \times 150 \mathrm{~mm} \times 150 \mathrm{~mm}$ were produced by partially replacing OPC with CCWP/BLA at $0 \%, 5 \%, 10 \%, 15 \%$ and $20 \%$. They were cured for 7, 21, 28 and 56 days in water and later brought out to be used for the compressive strength test in accordance with [12]. A concrete mix of ratio 1:2:4 (cement: sand: aggregates) were adopted to produce all the concrete cubes at water/cement ratio $(c / w)$ of 0.6. Mixed design was carried out for concrete of $\mathrm{C} 20 / 25$ using the procedure for the design of normal concrete mixes. The constituent materials were batched by weight as shown in Table 1 . The mix produced with only cement as binder served as the control mix. Summary of the mix design is as presented in Table 2. Also, various cement pastes with mix ratio 1:6 (cement: sand) of $50 \mathrm{~mm} \times 50$ $\mathrm{mm} \times 50 \mathrm{~mm}$ dimension were made with the cement partially replaced with CCWP and BLA at $0 \%$ and CCWP/BLA 10\%. The pastes were cured for 28 days duration and then analyzed using scanning electron microscopy (SEM) studies.

Compressive Strength and Bulk Density. Density of cubes was determined using Equation (6) and the compressive strength of 60 cubes was determined using Equation (7).

Table 1. Summary of materials for the mix design.

\begin{tabular}{cccccc}
\hline \multirow{2}{*}{ Materials } & \multicolumn{5}{c}{ Quantities $(\mathrm{kg})$} \\
\cline { 2 - 6 } & $\begin{array}{c}\text { OPC } \\
(0 \%)\end{array}$ & $\begin{array}{c}\text { CCWP/BLA } \\
(5 \%)\end{array}$ & $\begin{array}{c}\text { CCWP/BLA } \\
(10 \%)\end{array}$ & $\begin{array}{c}\text { CCWP/BLA } \\
(15 \%)\end{array}$ & $\begin{array}{c}\text { CCWP/BLA } \\
(20 \%)\end{array}$ \\
\hline Cement (kg) & 12.50 & 11.88 & 11.25 & 10.63 & 10.00 \\
BLA (kg) & 0.00 & 0.31 & 0.63 & 0.94 & 1.25 \\
CCWP (kg) & 0.00 & 0.31 & 0.63 & 0.94 & 1.25 \\
Water (kg) & 7.50 & 7.50 & 7.50 & 7.50 & 7.50 \\
Sand (kg) & 25.00 & 25.00 & 25.00 & 25.00 & 25.00 \\
Granite & 50.00 & 50.00 & 50.00 & 50.00 & 50.00 \\
Water/cement & 0.60 & 0.60 & 0.60 & 0.60 & 0.60 \\
ratio & & & & & \\
\hline
\end{tabular}


Table 2. Number of specimens and age for each test.

\begin{tabular}{llllll}
\hline \multirow{2}{*}{ Tests } & \multicolumn{4}{c}{ Duration (Days) } \\
\cline { 3 - 6 } & CCWP/BLA 0\% & $\mathbf{7}$ & $\mathbf{2 1}$ & $\mathbf{2 8}$ & $\mathbf{5 6}$ \\
\hline \multirow{3}{*}{ Number of } & 3 & 3 & 3 & 3 \\
Specimen & CCWP/BLA 5\% & 3 & 3 & 3 & 3 \\
& CCWP/BLA 10\% & 3 & 3 & 3 & 3 \\
& CCWP/BLA 15\% & 3 & 3 & 3 & 3 \\
& CCWP/BLA 20\% & 3 & 3 & 3 & 3 \\
\hline
\end{tabular}

$$
\text { Density of concrete }\left(\mathrm{kg} / \mathrm{m}^{3}\right)=M / V
$$

where; $M=$ weight of dry concrete cube, $V=$ Volume of dry concrete cube (150 $\mathrm{mm}$ by $150 \mathrm{~mm}$ by $150 \mathrm{~mm}$ ).

$$
\text { Compressive Strength }\left(\mathrm{N} / \mathrm{mm}^{2}\right)=F / A
$$

where;

$$
\begin{aligned}
& F=\text { Crushing load }(\mathrm{N}) ; \\
& A=\text { Cross Sectional Area of the concrete cube in } \mathrm{mm}^{2}(150 \mathrm{~mm} \text { by } 150 \mathrm{~mm}= \\
& \left.22,500 \mathrm{~mm}^{2}\right) .
\end{aligned}
$$

\section{Results and Discussions}

The results of the particle size distribution and the hygrometer test for sand (fine aggregate) is shown in Figure 1. This result showed that the sand was well graded. The results of the ACV and AIV for the granites chippings were $30.48 \%$ and $19.78 \%$ respectively as shown in Table 3, which are adequate for concrete of good impact resistance. This means that aggregates of higher impact values are weaker than aggregates with lower AIV. Therefore, the coarse aggregate used in the study is averagely adequate to produce concrete of good impact resistance. Aggregate Impact Value also indicates the degree to which the aggregates absorb shock. The result obtained from aggregate impact value test conducted on the coarse aggregate used in this research shows that the aggregate is impact resistance according to [13] [14] as its average AIV is less than 25\%. The result obtained from aggregate crushing value test conducted on the coarse aggregate used in this research is shows that the average ACV of 30.48\% falls almost within the standard of $25 \%$ to $30 \%$ as specified by [14] [15]. The recommended maximum ACV stipulated in [14] for aggregates for concrete production is $30 \%$.

The X-ray fluorescence (XRF) spectrometry test was performed on the Calcium Carbide Waste Powder (CCWP), Bamboo Leaf Ash (BLA) and Ordinary Portland Cement (OPC). The result is given in Table 4. The sum of the percentage composition of the oxides $\mathrm{SiO}_{2}+\mathrm{Al}_{2} \mathrm{O}_{3}+\mathrm{Fe}_{2} \mathrm{O}_{3}$ is respectively $70.60 \%$ and $9.29 \%$ in the ash of bamboo leaf and powder of calcium carbide waste. According to [16], a pozzolan should have $70 \%$ minimum value for the sum of those oxides. Accordingly, Bamboo Leaf Ash (BLA) satisfies the requirements for a 


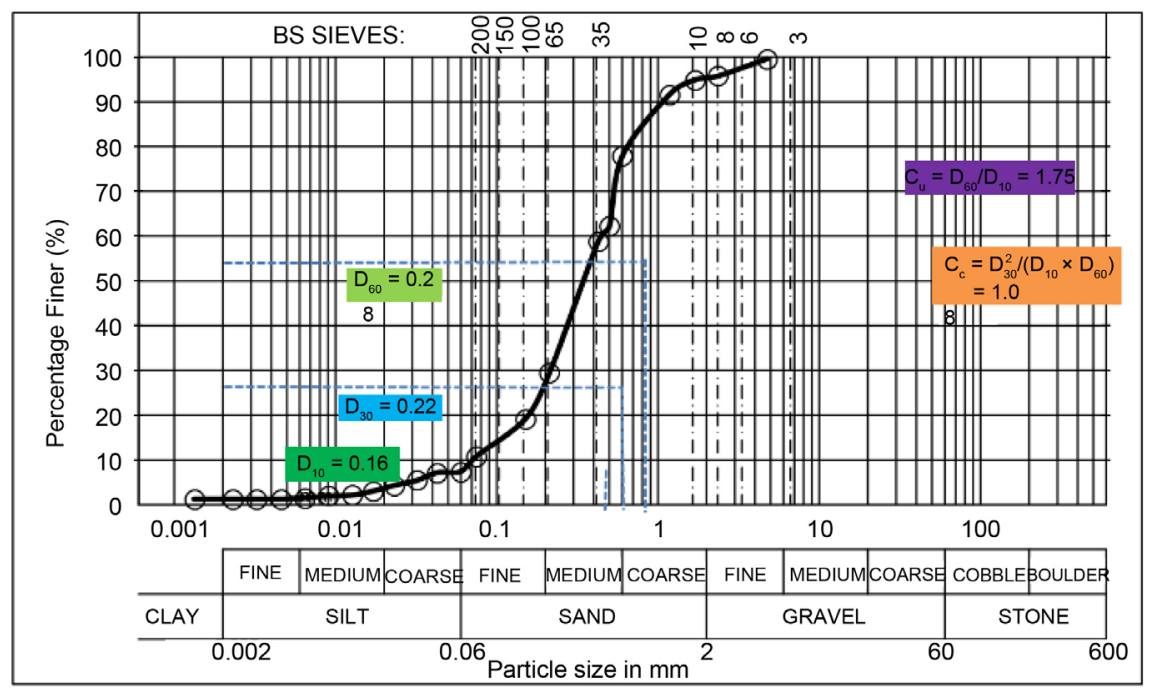

Figure 1. Particle size distribution chart for sand (sieve analysis and hydrometer analysis).

Table 3. Physical properties of materials used.

\begin{tabular}{|c|c|c|c|c|c|}
\hline $\begin{array}{l}\text { Physical Properties of All } \\
\text { Materials Used }\end{array}$ & $\begin{array}{c}\text { Fine } \\
\text { Aggregate } \\
\text { (Sand) }\end{array}$ & $\begin{array}{l}\text { Coarse } \\
\text { Aggregate } \\
\text { (Granite) }\end{array}$ & $\begin{array}{c}\text { Calcium } \\
\text { Carbide Waste } \\
\text { Powder } \\
(\text { CCWP })\end{array}$ & $\begin{array}{c}\text { Bamboo } \\
\text { Leaf Ash } \\
\text { (BLA) }\end{array}$ & $\begin{array}{c}\text { Ordinary } \\
\text { Portland } \\
\text { Cement } \\
\text { (OPC) }\end{array}$ \\
\hline Moisture content (\%) & 0.47 & - & - & - & - \\
\hline Bulk Density $\left(\mathrm{g} / \mathrm{cm}^{3}\right)$ & 1.788 & - & - & - & - \\
\hline Silt/Clay Content (\%) & 5.56 & - & - & - & - \\
\hline Fineness content (\%) & - & - & 100 & 100 & 99.72 \\
\hline Soundness $(\mathrm{mm})$ & - & - & $<10$ & $<10$ & $<10$ \\
\hline Specific Gravity & 2.64 & 2.61 & 2.93 & 2.32 & 3.13 \\
\hline $\operatorname{AIV}(\%)$ & - & 19.78 & - & - & - \\
\hline $\operatorname{ACV}(\%)$ & - & 30.48 & - & - & - \\
\hline Water Absorption (\%) & - & 0.93 & - & - & - \\
\hline Loss on Ignition (\%) & - & - & 16.62 & 5.23 & - \\
\hline
\end{tabular}

pozzolan while Calcium Carbide Waste Powder doesn't satisfy the requirement for a pozzolan (a non-pozzolan material). The chemical composition of the cement is also satisfactory and has met the standard [17]. In addition, magnesium oxide which more than $4 \%$ would make the pozzolan to be unsound was $1.18 \%$ in Bamboo Leaf Ash (BLA) which implies that it's far less than $4 \%$ and not detected in Calcium Carbide Waste Powder, which implies that it could only be present in trace quantities. The loss on ignition for the pozzolans is far less than 
Table 4. Chemical composition of Calcium Carbide Waste Powder (CCWP), Bamboo Leaf Ash (BLA) and Ordinary Portland Cement (OPC).

\begin{tabular}{cccc}
\hline \multirow{2}{*}{ Chemical Oxide } & \multicolumn{3}{c}{ Percentage Composition (\%) } \\
\cline { 2 - 4 } & $\mathrm{BLA}$ & CCWP & OPC \\
\hline $\mathrm{SiO}_{2}$ & 67.41 & 6.69 & 22.00 \\
$\mathrm{Al}_{2} \mathrm{O}_{3}$ & 1.95 & 2.30 & 3.11 \\
$\mathrm{Fe}_{2} \mathrm{O}_{3}$ & 1.24 & 0.30 & 4.65 \\
$\mathrm{CaO}$ & 16.99 & 89.76 & 62.00 \\
$\mathrm{MgO}$ & 1.18 & $\mathrm{ND}$ & 2.06 \\
$\mathrm{MnO}$ & 0.19 & $\mathrm{ND}$ & 0.32 \\
$\mathrm{ZnO}$ & 1.18 & $\mathrm{ND}$ & 0.86 \\
$\mathrm{~K}$ & 1.27 & 0.09 & 0.40 \\
$\mathrm{LOI}$ & 5.33 & 16.62 & - \\
\hline
\end{tabular}

the maximum permissible value of $10 \%$ as specified by ASTM. This indicates that there is only very little unborn carbon, a substance which reduces the pozzolanic activity of the ashes if present in amounts greater than $10 \%$. The pozzolanic activity of the investigated bamboo leaf ash is therefore not inhibited by the presence of unborn carbon.

As shown in Table 5, effect of partial replacement of OPC with CCWP and BLA on compressive strength was investigated using at $0 \%, 5 \%, 10 \%, 15 \%$ and $20 \%$ percentage replacement. The results of the compressive strength obtained for 7 days, 21 days, 28 days and 56 days are shown in Figure 2(a) and Figure 2(b) respectively. It can be observed from the result that the compressive strength increases with increase in the percentage replacement of BLA and CCWP at 7, 21, 28 and 56 days curing. The point of maximum compressive strength lies at $10 \%$ OPC replacement for CCWP/BLA while almost the same value of strength was obtained for OPC and the CCWP/BLA at $15 \%$. At $20 \%$ replacement, there is a drastic reduction in the compressive strength of the concrete. These results show that some strength forming reactions takes place when these wastes were partially used to replace cement from $0 \%$ to $20 \%$, after which the reactions reduces, and the compressive strength dropped. The phase of the optimum percentage replacement was studied using SEM studies.

As shown in Table 5, effect of partial replacement of OPC with CCWP and BLA on compressive strength was investigated using at $0 \%, 5 \%, 10 \%, 15 \%$ and $20 \%$ percentage replacement. The results of the compressive strength obtained for 7 days, 21 days, 28 days and 56 days are shown in Figure 2(a) and Figure 2 (b) respectively. It can be observed from the result that the compressive strength increases with increase in the percentage replacement of BLA and CCWP at 7, 21, 28 and 56 days curing. The point of maximum compressive strength lies at $10 \%$ OPC replacement for CCWP/BLA while almost the same value of strength was obtained for OPC and the CCWP/BLA at $15 \%$. At $20 \%$ replacement, there is a drastic reduction in the compressive strength of the 
Table 5. Compressive strength of concrete with varying quantity of CCWP and BLA replacements.

\begin{tabular}{ccccc}
\hline \multirow{2}{*}{$\begin{array}{c}\text { CCWP/BLA } \\
\text { Replacement }\end{array}$} & \multicolumn{4}{c}{ Compressive Strength $\left(\mathrm{N} / \mathrm{mm}^{2}\right)$} \\
\cline { 2 - 5 } & 7 days & 21 days & 28 days & 56 days \\
\hline 5 & 9.57 & 10.60 & 12.07 & 15.17 \\
10 & 9.93 & 11.83 & 13.23 & 15.97 \\
15 & 8.07 & 10.97 & 11.90 & 14.10 \\
20 & 7.23 & 9.70 & 10.50 & 12.87 \\
\hline
\end{tabular}

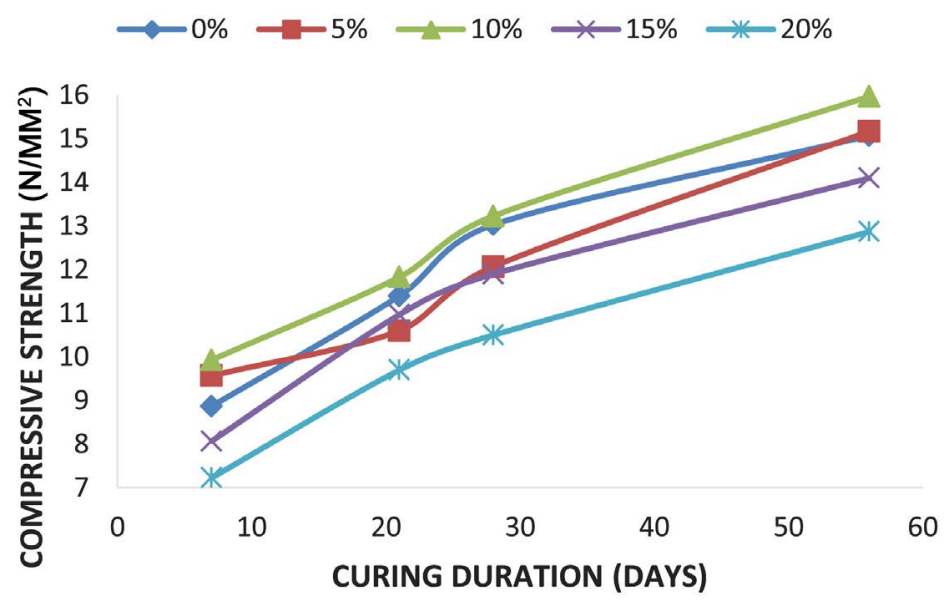

(a)

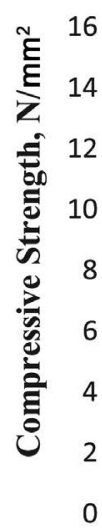

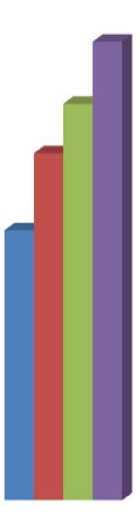

0

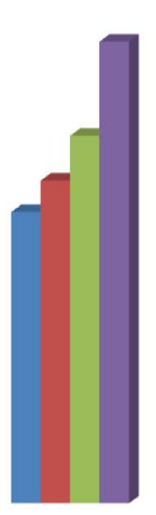

5

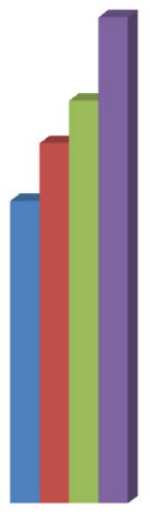

10

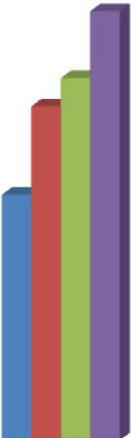

15

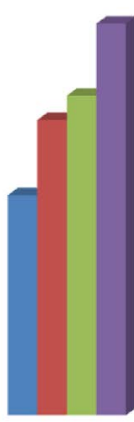

20

\section{CCWP/BLA Replacement (\%)}

๑ Days $\square 21$ Days $\square 28$ Days $\square 56$ Days

(b)

Figure 2. (a) Trend of compressive strengths of CCWP/BLA blended cement concrete. (b) Relationship between compressive strength results of CCWP/BLA blended cement concrete.

concrete. These results show that some strength forming reactions takes place when these wastes were partially used to replace cement from $0 \%$ to $20 \%$, after which the reactions reduces, and the compressive strength dropped. The phase of the optimum percentage replacement was studied using SEM studies. 
The results of the setting times are shown in Table 6 . It is seen that the OPC has an initial setting time of 85 minutes and final setting time of 588 minutes. The replacement of OPC with BLA and CCWP was prolonged. Addition of CCWP to BLA-cement mixture resulted in an increase in setting times at $10 \%$ CCWP, after which increase in setting times was observed with further addition of CCWP (see Table 6). Increase in setting times with CCWP and BLA can be attributed to low heat liberated during the hydration of cement-CCWP-BLA mixture which is responsible for slow rate of moisture evaporation and stiffening of the paste, as compared to high heat liberation during the hydration of cement which aids evaporation of moisture and stiffening of cement paste. The low heat liberation can be attributed to reactivity loss associated with the use of CCWP arising from storage and decrease in heat liberated by cement as it is partially replaced with CCWP and BLA. From Table 7, the slump values simply mean the $100 \%$ OPC concrete has a medium degree of workability. This medium degree of workability improves to $15 \%$ replacement until a fall begins in $20 \%$ replacement. This means at $20 \%$ replacement, there was a low workability compared to the $100 \%$ OPC concrete (Figure 3).

Slump test result presented in Table 7 and Figure 4 indicated that slump values are within the range of $50-75 \mathrm{~mm}$. The results showed that the slump heights of the CCWP/BLA blended cement concrete increased from 5\% to $10 \%$ but it then drops as the replacement percentage increases. Compared to $100 \%$ OPC concrete, the slump values of $15 \%$ and $20 \%$ are low.

The results of the compaction factor tests performed in the fresh concretes are detailed in Figure 5. Comparing the results in Table 8, OPC concrete's compaction factor is lower than that of CCWP/BLA blended cement concrete.

From the chemical composition results in Table 4, magnesium oxide which

Table 6. Setting times test result.

\begin{tabular}{cccc}
\hline S/N & Replacement (\%) & $\begin{array}{c}\text { Initial Setting Time } \\
(\mathrm{min})\end{array}$ & $\begin{array}{c}\text { Final Setting Time } \\
(\mathrm{min})\end{array}$ \\
\hline 1 & 0 & 85 & 588 \\
2 & 5 & 75 & 632 \\
3 & 10 & 85 & 676 \\
4 & 15 & 105 & 702 \\
5 & 20 & 155 & 737 \\
\hline
\end{tabular}

Table 7. Slump test values for BLA, CCWP and Binary blended cement concrete.

\begin{tabular}{ccc}
\hline S/N & Percentage Replacement (\%) & CCWP/BLA Slump Heights $(\mathrm{mm})$ \\
\hline 1 & 0 & 58 \\
2 & 5 & 59 \\
3 & 10 & 61 \\
4 & 15 & 58 \\
5 & 20 & 54 \\
\hline
\end{tabular}


Table 8. Soundness values of CCWP/BLA blended cement paste.

\begin{tabular}{ccc}
\hline S/N & Replacement (\%) & L2-L1 \\
\hline 1 & 0 & 0 \\
2 & 5 & 0 \\
3 & 10 & 0 \\
4 & 15 & 1.0 \\
5 & 20 & 1.0 \\
\hline
\end{tabular}

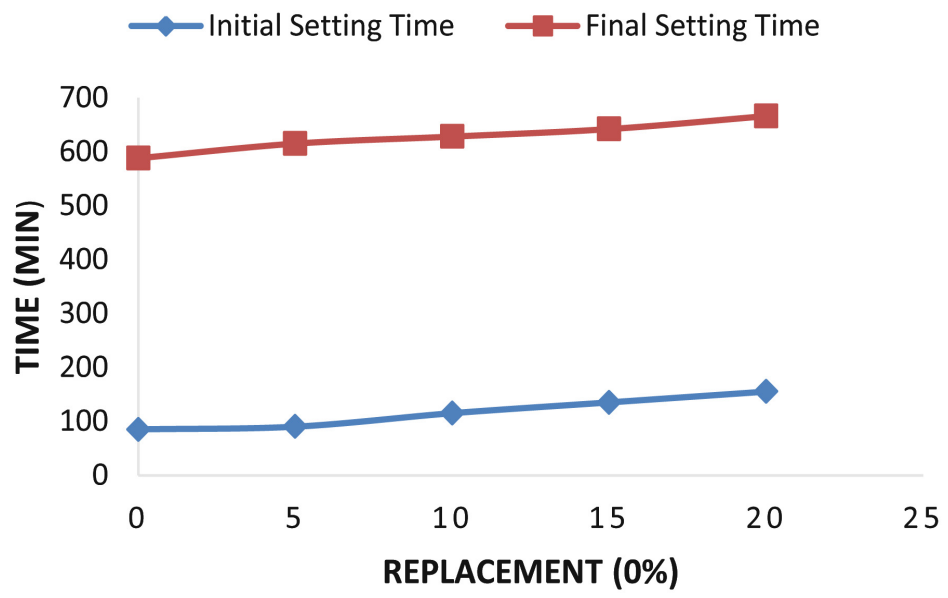

Figure 3. Setting time plot of CCWP/BLA blended cement concrete.

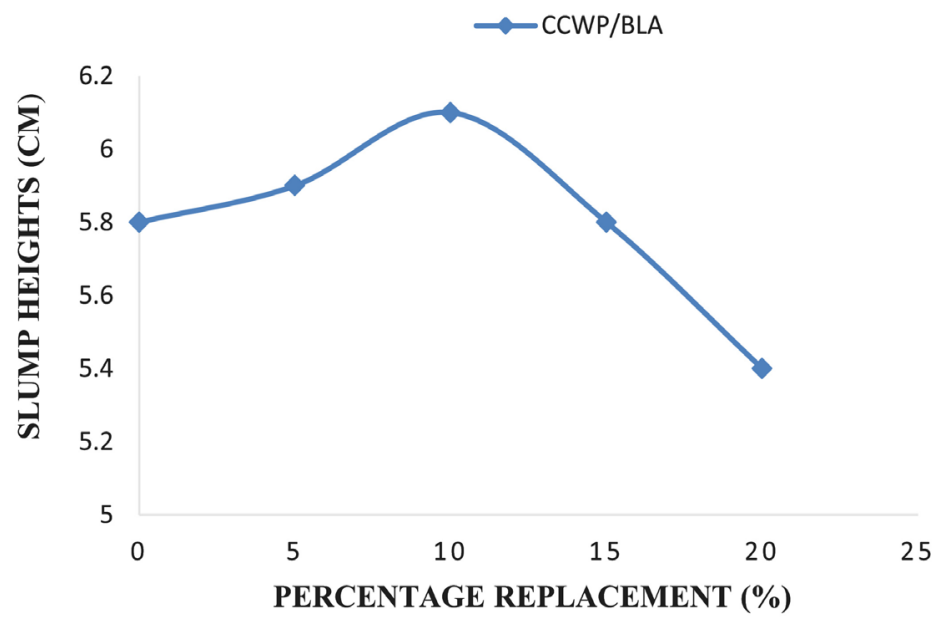

Figure 4. Variation of slump heights of calcium carbide waste powder and bamboo leaf ash blended cement concrete.

more than $4 \%$ would make the pozzolan to be unsound, was $1.18 \%$ in Bamboo Leaf Ash (BLA) which implies that it's far less than $4 \%$ and not detected in Calcium Carbide Waste Powder, which implies that it could only be present in trace quantities. With this, it makes the replacements sound up to $20 \%$ replacement (no expansion or shrinkage is up to or above $10 \mathrm{~mm}$.

L1 = Distance separating the indicator submerge in normal temperature water for 24 hours $(\mathrm{mm})$. L2 = Distance separating the indicator submerge in boiling 


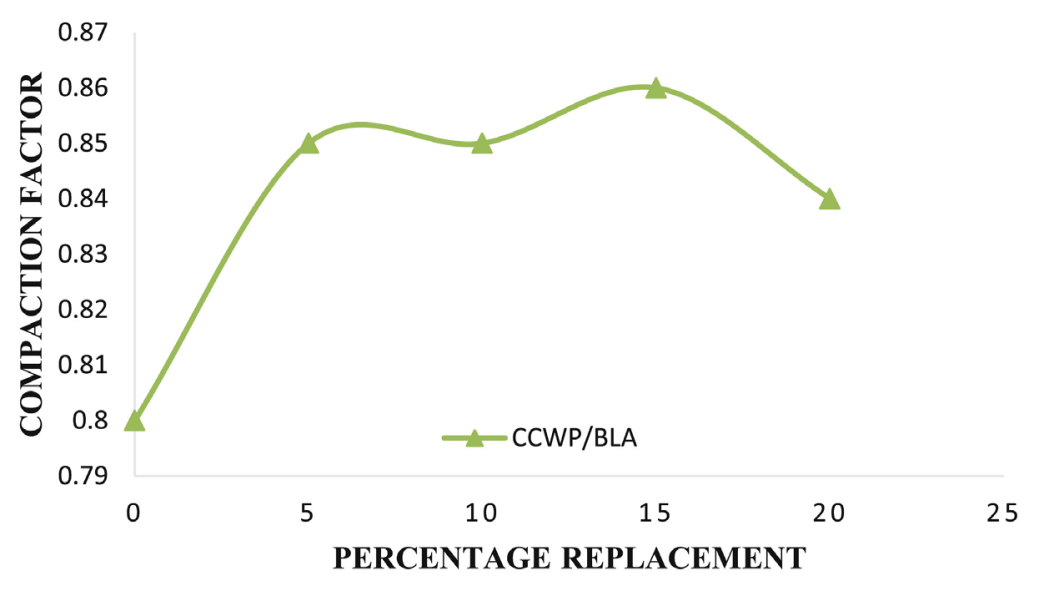

Figure 5. Compaction factor plot of OPC and CCWP/BLA blended cement concrete.

for 3 hours (mm).

The dry densities of the concrete from the various mixes are presented in Figure 6. The air-dry densities of the Ordinary Portland Cement (OPC) concrete cubes were between $2400.00 \mathrm{~kg} / \mathrm{m}^{3}$ and $2509.63 \mathrm{~kg} / \mathrm{m}^{3}$ between 7 and 56 days. As shown in Figure 6. The densities of BLA concrete cubes with Ordinary Portland Cement (OPC) varied from $2400.00 \mathrm{~kg} / \mathrm{m}^{3}$ to $2450.37 \mathrm{~kg} / \mathrm{m}^{3}$ at 7 days and from $2468.15 \mathrm{~kg} / \mathrm{m}^{3}$ to $2480.00 \mathrm{~kg} / \mathrm{m}^{3}$ at 28 days. The results show that concrete containing CCWP and BLA can be classified as structural normal weight concrete (NWC) as shown in the range of values of $2000 \mathrm{~kg} / \mathrm{m}^{3}$ to $2400 \mathrm{~kg} / \mathrm{m}^{3}$ for normal weight aggregate concretes, obtained in past studies (BS EN 12350-6, 2009). The higher densities of the NWC could be attributed to the higher specific gravity of the coarse and fine granite aggregates, higher sand to cement ratio and compactness (thus less voids) of the concrete mix.

The results of the SEM pictures for hydrated samples of OPC and CCWP/BLA $10 \%$ at 28 days curing are shown in Figure 7 and Figure 8 respectively. The white and black colours stand for the OPC particles and the interlocking spacing between the particles respectively in Figure 7 while the white colour stands for OPC, BLA, CCWP particles and black colour is the spacing in Figure 8. The results show that the image of CCWP/BLA $10 \%$ is tightly interlocked just like the image of OPC, though that of OPC gives a better interlocking. This result further supports that addition of pozzolanic material (OPC) and non-pozzolanic material (CCWP) to concrete will improve the micro structural property of such concrete which in turn will improve other properties like compressive strength, workability, density, durability etc. The optimum percentage replacement of BLA/CCWP should be adhered to for effective performance.

\section{Conclusions}

From the study, the following conclusions were drawn:

- Oxide composition analysis of calcium carbide waste powder (CCWP) shows that CCWP is a no-pozzolanic material with high $\mathrm{CaO}$ content, and low $\mathrm{SiO}_{2}$ 


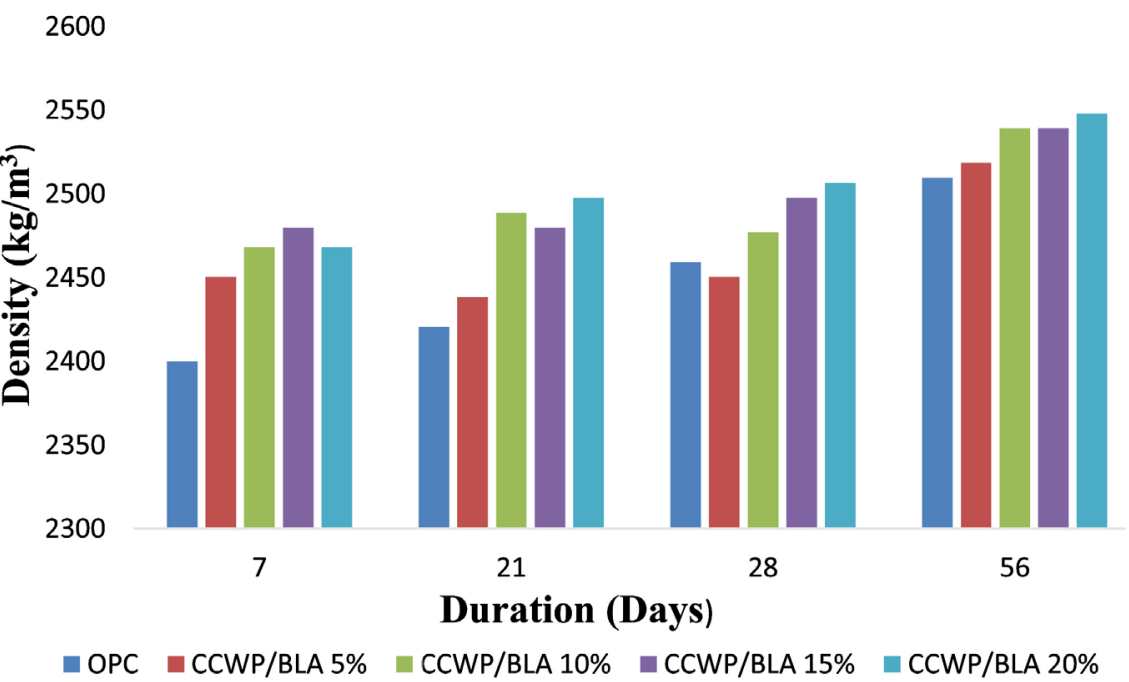

Figure 6. Dry density of CCWP/BLA blended cement concrete.

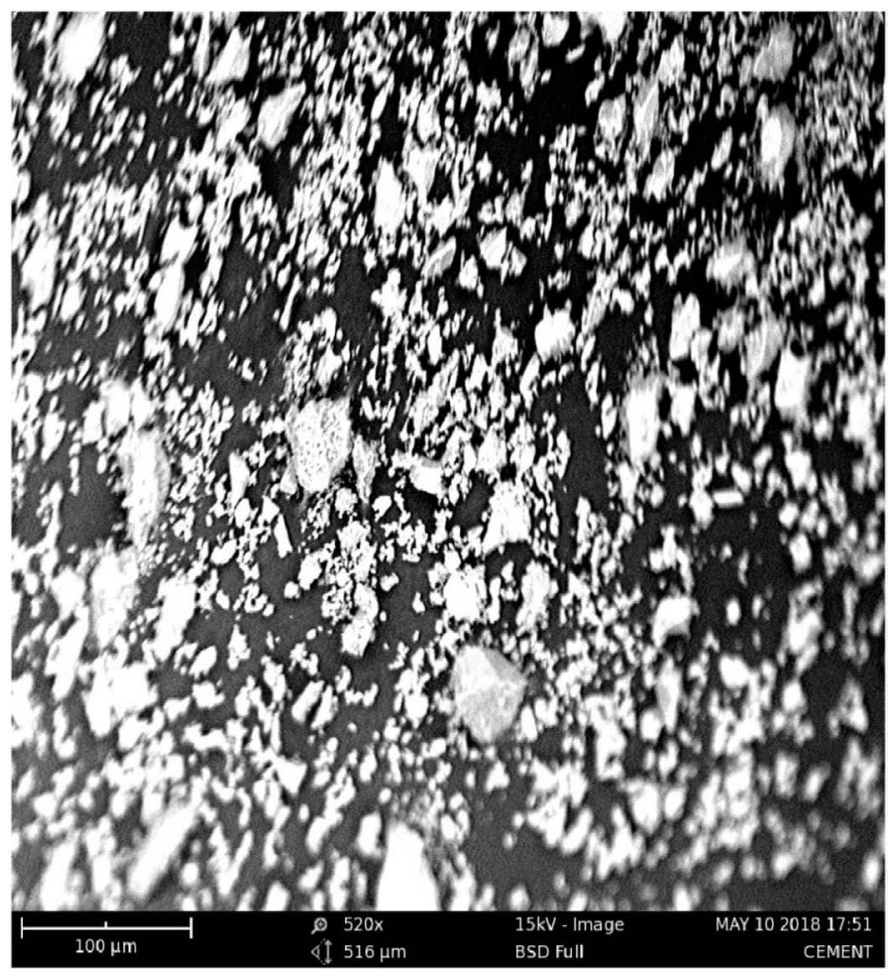

Figure 7. Micrograph of developed sample of OPC with 520 magnification.

content, while bamboo leaf ash (BLA) is a pozzolanic material rich in silicon oxide $\left(\mathrm{SiO}_{2}\right)$ component as shown in Table 4.

- Setting times of CCWP/BLA-cement combination increased with CCWP and BLA content in paste made with cement partially replaced with the two wastes.

- Compressive strength results show that CCWP and BLA have positive effects on the strength of concrete made with the two wastes. 


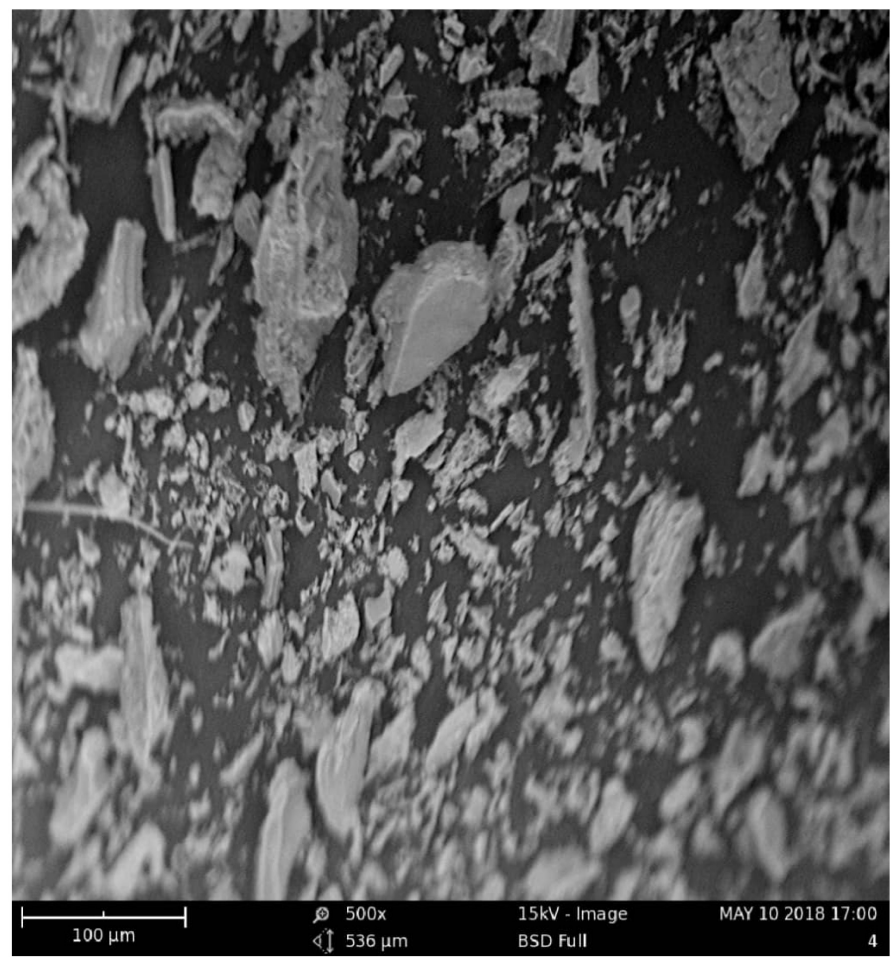

Figure 8. Micrograph of developed sample of OPC/CCWP/BLA with 520 magnification.

- Compressive strength test result of concrete made exhibited great improvement with the addition of $10 \%$ CCWP/BLA after which a decline in compressive strength was observed.

- Hence, the recommendation of a combination of $10 \%$ CCWP/BLA for use is in concrete products for construction, because peak compressive strength at this replacement level is comparable with result obtained with the use of only cement as binder.

- Also, efforts should be made to keep CCWP and BLA sealed after grinding, sieving and burning. They should be kept in a dry area to prevent them from moisture attack, which may reduce its strength.

\section{Conflicts of Interest}

The authors declare no conflicts of interest regarding the publication of this paper.

\section{References}

[1] Hardjito, D., Antoni, Wibowo, G.M. and Christtianto, D. (2012) Pozzolanic Activity Assessment of Mud in Semi High Volume Pozzolanic Mortar. Materials, 5, 1654-1660. https://doi.org/10.3390/ma5091654

[2] Elinwa, A.U., Ejeh, S.P. and Akpabio, I. (2005) Using Metakaolin to Improve Sawdust Ash Concrete. Concrete International, 27, 49-52.

[3] Olugbenga, A. (2007) Effects of Varying Curing Age and Water/Cement Ratio on the Elastic Properties of Laterized Concrete. Civil Engineering Dimension, 9, 85-89. 
[4] Bakar, B.H., Putrajaya, R.C. and Abdulaziz, H. (2010) Malaysian Saw Dust AshImproving the Durability and Corrosion Resistance of Concrete: Pre-Review. Concrete. Research Letters, 1, 6-13

[5] Padney, S.P., Singh, A.K., Sharma, R.L. and Tiwari, A.K. (2003) Studies on High-Performance Blended/Multi-Blended Cements and Their Durability Characteristics. Cement and Concrete Research, 33, 1433-1436. https://doi.org/10.1016/S0008-8846(03)00091-7

[6] Makaratat, N., Jaturapitakkul, C., Namarak, C. and Sata, V. (2011) Effects of Binder and $\mathrm{CaCl} 2$ Contents on the Strength of Calcium Carbide Residue-Fly Ash Concrete. Cement and Concrete Composites, 33, 436-443.

[7] Sun, H., et al. (2015) Properties of Chemically Combusted Calcium Carbide Residue and Its Influence on Cement Properties. Materials, 8, 638-651.

https://doi.org/10.3390/ma8020638

[8] Beckhoff, B. (2006) Handbook on Practical X-Ray Fluorescence Analysis. Springer, Berlin. https://doi.org/10.1007/978-3-540-36722-2

[9] Ikumapayi, C.M. (2016) Crystal and Microstructure Analysis of Pozzolanic Properties of Bamboo Leaf Ash and Locust Beans Pod Ash Blended Cement Concrete. Applied Science Environment Management, 20, 943-952.

https://doi.org/10.4314/jasem.v20i4.6

[10] (1992) Specification for Aggregates from Natural Sources for Concrete. British Standard International, London, BS 882.

[11] (2009) Testing Fresh Concrete Density of Test Specimens. British Standard, London, BS EN 12350-6.

[12] (2009) Testing Hardened Concrete Part 3. British Standard International, London, BS EN 12390-3.

[13] (1992) Specification for Aggregates from Natural Sources. British Standard International, London, BS 882.

[14] (1990) Testing Aggregates, Method for Determination of Aggregate Impact Value (AIV). British Standard International, London, BS 812.

[15] (1963) Method of Test for Aggregates for Concrete. British Standard International, London, IS2386-4.

[16] ASTM (1994) America Standard Testing Methods for Sampling.

[17] (2000) British Standard for Cement Composition Specification and Conformity for Common Cements. British Standard International, London, BS EN 197. 